\title{
The Impact of Training Program and Work Experiences on Career Development
}

\author{
Ni Putu Sri Sukmawati ${ }^{1}$, Agoes Ganesha Rahyuda ${ }^{2}$, Wayan Gede Supartha ${ }^{3}$ \\ Fakultas Ekonomi dan Bisnis, Universitas Udayana, Bali, Indonesia ${ }^{1,2,3}$ \\ agoesgrahyuda@unud.ac.id ${ }^{2}$
}

\begin{abstract}
Managers should pay attention to the development of their employees' career if they wish to get a fully committed and satisfied employee to work for them. Unfortunately, the literature could not provide a clear guidance about the factors that might contribute to the development of employee career in the context of developing countries. The purpose of this paper is to explore the effect of training program and work experiences on career development, either directly or via employee skills. This research was conducted at Denpasar Social Affairs Office, with the number of samples was 67 employees. Data was collected through the help of questionnaire, and was analyzed with path analysis. The results show that training program and work experiences influence employees' career development. Furthermore, employee skills also provide an impact to the career development. Finally, it can be found that employee skills play a role as mediating variable in the relationship between training program or work experiences and career development.
\end{abstract}

Keywords: Career Development, Employee Skills, Training, Work Experience

\section{Introduction}

One of the important factors that influence the performance of an employee is a good career development system in the organization. Career development is the process of improving the ability of individual work accomplished in order to achieve the desired career [1] The highly influential career development on performance of employees[2]. In addition, Harlie stated that there was a direct influence on career development and performance among employees[3]. This suggests that the development of career employees in the organization then the higher performance levels of their employees. Although the development of the career is important, but there is still the problem of a career on the city's Social Service. Based on observation, it is known that several employees of the less skilled and less diligent in taking care of the promotion files. Some of the interviews also indicate that they are less confident if it should be moved to another position because they had to learn from scratch or they lack of experience if it should be in the new position. However, this caused the dissatisfaction of employees because it has not been able to reach a certain level or a position that you want. In addition, some employees expect information about promotional opportunities socialized with clear, because sometimes some employees were less aware of the promotional opportunities. Career development is a concept 
that is important to individuals and organizations so that the problem popped up need to be addressed by way of understanding the factors which affected it.

\section{Method}

The location of the study was conducted at the Denpasar City Social Service on Jalan Mulawarman No. 2 Denpasar. The population in this study were permanent employees and contract employees in the Denpasar City Social Service, which amounted to 67 people. The method of determining the sample used in this study is saturated sampling. The sample used in this study is all members of the population, namely as many as 67 permanent employees and contract employees. Data collection in this study uses several methods, interviews and questionnaires. This study uses multiple linear analysis techniques. Calculation of path coefficients requires calculations from correlation and regression analysis which are then poured in software in the form of SPSS for windows.

\section{Result}

Characteristics of respondents based on demographic variables consisting of gender, age, position, overall work experience and work experience in the last position are presented in Table 1. below.

Table 1 Respondent Characteristic

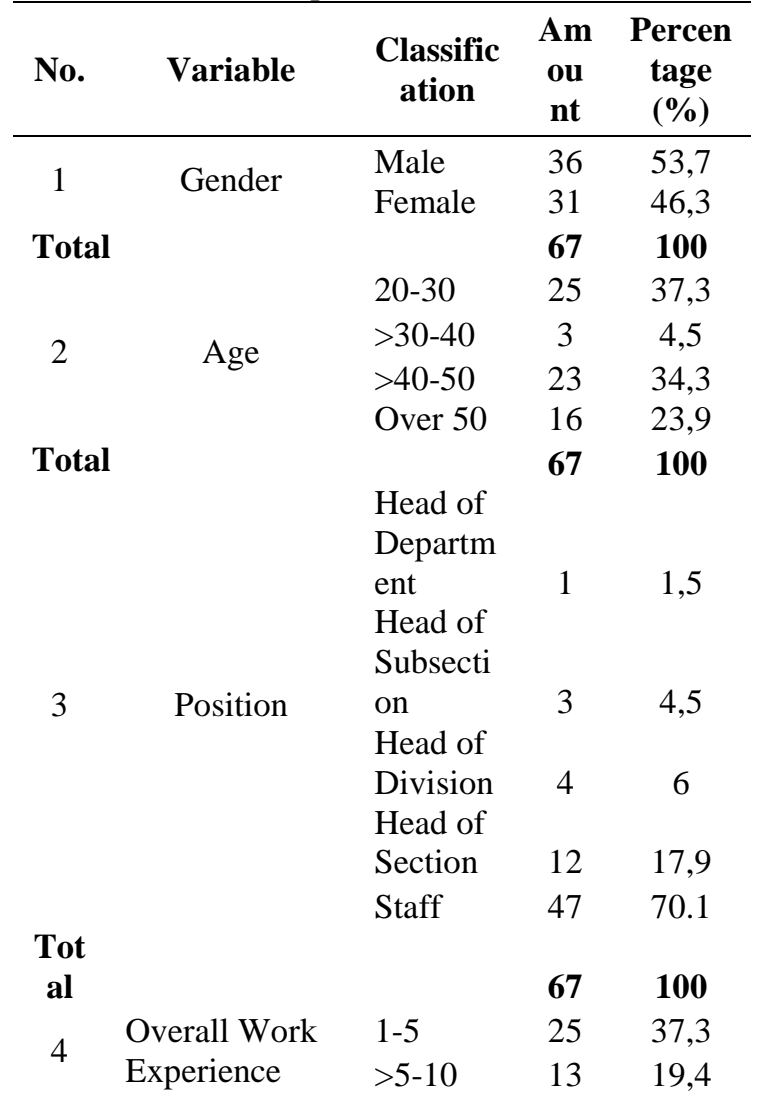




\begin{tabular}{ccccc} 
& & $>10-20$ & 19 & 28,3 \\
$\begin{array}{c}\text { Tot } \\
\text { al }\end{array}$ & & over 20 & 10 & 15 \\
& & & & \\
\multirow{4}{*}{5} & Work & $1-5$ & 37 & $\mathbf{1 0 0}$ \\
& Experience in & $>5-10$ & 18 & 26,9 \\
& the Last & $>10-20$ & 9 & 13,4 \\
& Position & over 20 & 3 & 4,5 \\
Total & & & $\mathbf{6 7}$ & $\mathbf{1 0 0}$ \\
\hline
\end{tabular}

Source: Data Proceed, 2018

Based on the data on the respondents' characteristics in table 1, it can be seen that for the gender class respondents tend to be dominated by male, that is equal to 53.7 percent compared to the percentage of respondents who are female only 46.3 percent. This shows that there are more male respondents than women.

Furthermore, when viewed from the age of the respondents, the majority are 20-30 years old, which is 37.23 percent, followed by the age group $>40-50$ years, 34.3 percent, the age group above 50 years is 23.9 percent and finally the age group $>30-40$ by 4.5 percent.

The next classification is the classification of positions, which in this study were dominated by staff which amounted to 70.1 percent, then classification of cations of 17.9 percent, classification of districts by 6 percent, then classification of head of departments 4.5 percent and the last classification of heads by 1.5 percent.

Classification based on the overall experience of dominant employees 1-5 years worked with a percentage of 37.3 percent, then above 10-20 years with a percentage of 28.3 percent, then above 5-10 years with a percentage of 19.4 percent and the last over 20 years with 15 percent.

The last classification is the experience-based classification in the last position of the dominant employee 1-5 years working with a percentage of 55.2 percent, then over 5-10 years with a percentage of 26.9 percent, then above 10-20 years with a percentage of 13.4 percent and those with last over 20 years with a percentage of 4.5 percent.

Table 2 Results of Multiple Linear Regression Analysis

Unstandardized Coefficients Standardized Coefficients T Sig

B Std. Beta Error

1 (Constant) -, 142 1,075 -, 132, 895

Training, 235, 082, 220 2,863, 006

Work Experience, 280, 076, 293 3,681,000

Working Skills, 706, 129, 488 6,457,000

This study has seven hypotheses which are then compiled into a regression model. The following are the hypotheses and models in Table 2.

Source: Data processed, 2018 
The value of $\beta 1$ of 0.488 means that work skills have a positive effect on career development, in other words if the work skill factor increases then career development will increase by 0.488 .

B2 value of 0.220 means training has a positive effect on career development, in other words if the training factor increases, career development will increase by 0.220 .

The value of $\beta 3$ of 0.293 means that work experience has a positive effect on career development, in other words if the work experience factor increases, career development will increase by 0,293 .

\section{Discussion}

\subsection{Effects of Training on Career Development}

Based on the results of testing the training hypothesis has a positive effect on work skills obtained Beta coefficient value of 0.443 with a significance level of $0.000(\leq 0.05)$ which indicates $\mathrm{H} 0$ is rejected and $\mathrm{H} 1$ is accepted. This means that effective training allows employees to get the skills and competencies needed in carrying out certain tasks, so that the more employees get training the skills increase. This is in accordance with the theory examined by Donald E. Super which proclaims a view on the development of careers whose scope is very broad and includes many individual and environmental factors. The results of this study who found that training had a positive effect on career development. The research provides strong evidence that training and career development programs have a positive relationship[5]. Research conducted by Olaniyan states that training is needed for staff to enable them to work towards the expected goals of the organization[6]. A significant influence on career development variables[7]. The training has a positive and significant effect on career development[8].

\section{a. Influence of Work Experience on Career Development}

Based on the results of testing the work experience hypothesis has a positive effect on career development, the Beta coefficient value is 0.293 with a significance level of $0.000(\leq 0.05)$ which indicates $\mathrm{H} 0$ is rejected and $\mathrm{H} 1$ is accepted. This means that the high level of work experience will help employees have a good career, so that the higher the work experience of an employee, the greater the opportunity in developing his career. This is in accordance with the theory examined by Donald E. Super which proclaims a view on the development of careers whose scope is very broad and includes many individual and environmental factors. The work experience has a positive and significant influence on the career development of an employee[8]; [9]. The work experience to have a positive and significant influence on career development[10]. The work experience has a significant effect on career development[11]. The work experience has a positive relationship to develop a career[12]. The influence of direct relationships that can be seen between skills and employment variables with the level of career development of part-time workers[13].

\section{b. Effect of Skills on Career Development}

Based on the results of hypothesis testing, the analysis of the effect of work skills on career development is obtained by the Sig t value. amounting to 0,000 with a beta coefficient of 0.488 . Sig value. $\mathrm{t} 0,000<0,05$ indicates that $\mathrm{H} 0$ is rejected $\mathrm{H} 1$ is accepted. This result means that work skills have a significant effect on the career development of Denpasar City Social Service employees. A positive relationship between skills and career development[14]. There is a positive and significant influence between skills towards career development, meaning that the level of career development of employees is also determined by the skills they have[15]. 


\section{Conclusion}

Conclusions that can be drawn based on the results of the analysis is the positive effect of training towards the development of a career. Training a positive effect against job skills. Work experience a positive effect towards the development of a career. Work experience a positive effect against job skills. Job skills positive effect towards the development of a career. Job skills acts as a mediation on the influence of training towards the development of a career. Job skills acts as a mediating influence on work experience towards the development of a career.

\section{References}

[1] V. Rivai, Manajemen Sumber Daya Manusia Untuk Perusahaan. Jakarta: PT. Raja Grafindo Persuade, 2011.

[2] M. Djamaludin, "Pengaruh Komitmen Organisasional, Pengembangan Karir, Motivasi, dan Karakteristik Individual Terhadap Kepuasan Kerja dan Kinerja Pegawai Pemerintah Kabupaten Halmahera Timur.," J. Ilmu Ekon. Dan Manaj., vol. 5, no. 2, hlm. 1-79, 2009.

[3] M. Harlie, "Pengaruh Disiplin Kerja, Motivasi, dan Pengembangan Karir Terhadap Kinerja Pegawai Sipil pada Pemerintah Kabupaten Tabalong di Tanjung Kalimantan Selatan," J. Apl. Manaj., vol. 10, no. 4, hlm. 860-867, 2012.

[4] N. Ratnaningsih, "Pengaruh Pendidikan dan Pelatihan Terhadap Pengembangan Karir Pegawai BPPNI Regional IV Surabaya,” J. Pendidik., vol. 31, no. 4, hlm. 145-162, 2011.

[5] J. Purcell, N. Kinnie, S. Hutchinson, B. an. S. Rayton, dan J., Understanding the People and Performance Link: Unlocking the Black-Box. London: Research Report, CIPD, 2003.

[6] D. A. O. Olaniyan dan L. B, "Staff Training and Development: A Vital Tool For Organizational Effectiveness," Eur. J. Sci. Res., vol. 24, no. 3, hlm. 326-331, 2008.

[7] M. Muis, Analisis Faktor-faktor yang Mempengaruhi Pengembangan Karir Karya. 2009.

[8] I. Labbase, "Faktor-faktor yang Berpengaruh Terhadap Pengembangan Karir Pegawai Dinas Periklanan dan Kelautan Provinsi Sulawesi Selatan," J. Econ. Resour., vol. 11, no. 31, hlm. 127-144, 2010.

[9] H. Nofiarsyah, "Analisis Faktor-Faktor yang Mempengaruhi Pengembangan Karir Pegawai Negeri Sipil Pada Kantor Secretariat Daerah Kabupaten Kutai Barat," J. Lembusuana, vol. 9, no. 96, hlm. 15-19, 2009.

[10] P. Mcllveen, "A Longitudinal Study of The Experience of A Career Development Program For Rural School Students," Career Educ. High. Educ., vol. 3, no. 1, hlm. 1114, 2012.

[11] J. . A. . Sagung Siskarini, "Pengaruh Prestasi Kerja, Pendidikan, Pengalaman Kerja, Pengenalan dan Kesempatan Untuk Tumbuh Terhadap Pengembangan Karir Pegawai Negeri Sipil Pada Kantor Dinas Ketentraman Ketertiban dan Satuan Polisi Pamong Praja Kota Denpasar.," E-J. Manaj. Univ. Udayana, vol. 9, no. 2, hlm. 42-45, 2013.

[12] G. Dokko, S. L. W. Rothbard.2008, dan N. P., "Unpacking Prior Experience How Career History Affects Performance," Artic. Adv., vol. 6, no. 10, hlm. 1-18.

[13] T. Sekiguchi, "Park-Time Work Experience of University Students and Their Career Development.," Jpn. Labour Rev., vol. 9, no. 3, hlm. 5-29, 2012.

[14] G. BrigMason, "High Skills Utilization Unde Mass Higher Education: Graduate Employment In Service Industies In Britain," J. Educ. Work, vol. 15, no. 4, hlm. 427456, 2002.

[15] Kustini, "Pengaruh Kompetensi Pengetahuan dan Ketrampilan Terhadap Kinerja dan Pengembangan Karir Karyawan Stikes dan Akbid dr.Soebandi Jember," J. ISEI Jember, vol. 15, no. 6, hlm. 1-8, 2015. 